\title{
Cultura Cultura
}

Pevista de $\mathrm{Hi}$

Revista de História e Teoria das Ideias

Vol. 23 | 2006

Ideia(s) de Tempo(s)

\section{O leão e o borracho ou a história contemporânea entre a memória e o Taqlīd}

Em torno do Al-Mann bil- Imāma de Ibn Ṣāḥib al-Salāt

Lion and the pigeon or the contemporary history between memory and the

Taqlìd: on Ibn Șāhib al-Salāt's Al-Mann bil-Imama

\section{Hermenegildo Fernandes}

\section{(2) OpenEdition}

Journals

\section{Edição electrónica}

URL: http://journals.openedition.org/cultura/1492

DOI: $10.4000 /$ cultura. 1492

ISSN: 2183-2021

\section{Editora}

Centro de História da Cultura

\section{Edição impressa}

Data de publição: 1 Janeiro 2006

Paginação: 259-272

ISSN: 0870-4546

\section{Refêrencia eletrónica}

Hermenegildo Fernandes, « O leão e o borracho ou a história contemporânea entre a memória e o

Taqlīd », Cultura [Online], Vol. 23 | 2006, posto online no dia 15 abril 2014, consultado a 01 maio 2019.

URL : http://journals.openedition.org/cultura/1492; DOI : 10.4000/cultura.1492

Este documento foi criado de forma automática no dia 1 Maio 2019.

(c) CHAM - Centro de Humanidades / Centre for the Humanities 


\section{O leão e o borracho ou a história contemporânea entre a memória e o Taqlīd}

Em torno do Al-Mann bil- Imāma de Ibn Șāḥib al-Salāt

Lion and the pigeon or the contemporary history between memory and the

Taqlìd: on Ibn Șāhib al-Salāt's Al-Mann bil-Imama

Hermenegildo Fernandes

Para Luís Krus

"Este jovem parece um leão e o leão é indígena,
enquanto a pomba é estrangeira. Os almôadas
venceram os estrangeiros e devoraram-nos como
este jovem devora o borracho."
Ibn Șāḥib al-Salāt, Al-Mann bil-lmāma, p. 79.

No interior da tradição historiográfica constituída no quadro do al-Andalus, alguns textos há que se diferenciam pela sua posição intermédia entre o ta'rīH, a escrita da História propriamente dita, e a literatura memorialística. Entre eles avultam, pela extraordinária capacidade para, a partir de uma experiência individual vivida num momento de crise da sociedade andaluza, construir uma reflexão sobre a história do seu próprio tempo, como pelas alturas de uma teoria do poder a que se elevam, as memórias de 'Abd Allāh b. Bulluqqīn, ${ }^{1}$ um quase pós-fácio do período taifa, redigido no final do século XI pelo último rei zirida de Granada. Pouco menos de cem anos mais tarde, um outro andaluz, 'Abd alMalik b. Muḥammad Ibn Ṣạ̄ib al-Salāt, membro de uma notável família regional oriunda de Beja, utilizava o testemunho directo de muitos dos acontecimentos do seu tempo para construir uma história do regime que servia, o almôada, a qual, assumindo-se muito embora como um esforço de ta'rïH, revestia a espaços, talvez involuntariamente, um registo memorialístico. ${ }^{2}$ Não se trata, é verdade, de memórias comparáveis às de 'Abd Allāh. Nem o autor rompe com os procedimentos do género que cultiva, raramente 
assumindo uma primeira pessoa. Porém, como este, Ibn Șāhib enfrentava o dilema da submissão da sociedade andaluza a um poder exógeno não tanto porque berbere mas porque não arabizado, ou seja, não andaluz, de questionável legitimidade sob o ponto de vista do direito, porque exterior ao sector árabe da umma, mas de incontornável força política e militar. Como este ainda, escolherá a via da colaboração, levada aqui mais longe, como cumpria a um letrado provincial, cuja carreira dependia em grande medida da sua capacidade para integrar a burocracia do novo império. Como este, finalmente, no afã de escrever a história do que viu, não podia deixar de ser fortemente dominado pelas violentas convulsões a que ambos assistiram: no primeiro caso a resolução da fragmentação política do al-Andalus a favor dos invasores almorávidas que dita o fim de um certo mundo que vive ainda na fiç̧ão dos prestígios de uma memória califal omíada e legitimista; no segundo, a renovação política radical que implica a aceitação do domínio almôada, menos pela mudança na dinastia berbere dominante, que pela profundidade revolucionária implícita no seu programa, já na heterodoxia religiosa, já na dimensão do corte representado pela assumpção do título califal.

Dito isto, os resultados de cada uma das escritas não poderiam ser mais diversos. $\mathrm{O}$ antigo rei de Granada escreve para si tanto quanto para a posteridade e acerta contas, pela narração reflexiva, com o destino próprio de rei deposto. 0 historiador de Beja reconstrói, através de uma criteriosa crítica da sua memória pessoal, das alheias, e de múltiplas fontes escritas, a história dos seus senhores. Escreve, pois, mais para eles que para si mesmo, mesmo que muitas das memórias sejam as suas. Nele o historiador suplanta o memorialista. Os problemas de um são, porém, os do outro. $\mathrm{E}$ as bases ideológicas que presidem aos processos de elaboração das memórias, a pessoal incluída, e à produção final do texto histórico, neles largamente assentam.

3 Nessa segunda metade do século XII em que Ibn Șāhịib está intelectual e politicamente activo, duas questões fundamentais se colocavam às elites andaluzas de que ele fazia parte, iguais, mutatis mutandis, àquelas que enfrentam todas as oligarquias quando o seu espaço político se vê subitamente integrado num novo sistema de dominação: como manter o poder através de todas as mudanças, de molde a que, mudando tudo, tudo fique na mesma; como resolver as contradições decorrentes da sobreposição de um novo modelo ideológico dominante às velhas construções que sempre tinham sustentado o seu poder. No primeiro caso em jogo está a adequação das aristocracias urbanas árabes - ou reivindicantes de uma genealogia, isto é, de uma memória, árabe, o que vem a dar no mesmo - que haviam conhecido no século anterior uma singular possibilidade de expansão, tanto pelo global crescimento da economia urbana como pelo triunfo de um modelo de governo de base regional e virtualmente acentrado, ao novo e forçado recentramento numa autoridade central, a almôada, com uma capacidade de afirmação como não se via desde os tempos áureos do califado omíada, na segunda metade do século $\mathrm{X}$. No segundo a completa e radical alteridade do modelo ideológico e cultural que o novo regime traz consigo, assente por um lado numa clara assumpção da identidade cultural berbere face ao al-Andalus árabe e por outro - e sobretudo - numa visão do Islão absolutamente nova frente ao conservadorismo maliquita das élites andaluzas, que o meio século de domínio almorávida tinha acabado por consolidar. Assim, para letrados como Ibn Șāhib, a questão não está apenas em encontrar um termo de convivência com os novos senhores, mas mais ainda em ir negociando os moldes em que ela decorrerá, o que implica, em última instância, a adesão a um credo substantivamente outro. E aquilo que sabemos da sua carreira parece mostrar isso mesmo. 
O grosso das informações é ele próprio que no-las dá, disseminadas pela única parte sobrevivente do Al-Mann bil-Imāma. No prefácio à tradução que dele fez, A. Huici já elencou todos os dados que pôde respigar dispersos no texto, eloquentes na sua exiguidade. ${ }^{3}$ Os dicionários biográficos coevos e as nomina de ulemas que eles permitiram construir precisam o quadro, dando-lhe espessura geográfica e cronológica.

Do que o próprio nos diz sabemos que pertence a uma família da elite de Beja ${ }^{4}$ que forma, juntamente com outras, tal os Banū al-Anșāīī, a hāsșa da cidade no momento preciso em que esta, de resto já declinante, se está prestes a perder para os cristãos ${ }^{5}$ e, depois, a entrar num período de abandono que se manterá até depois da definitiva ocupação portuguesa, nos anos 30 ou 40 de Duzentos. Um primeiro dado que não deixa de ser importante para avaliar da visão que Ibn Șāhị tem da história enquanto fenómeno vivencial: durante a vida dele, a sua cidade epónima, que lhe dava a nisba de Al-Bājī, o de Beja, deixa de ser parte do al-Andalus. Mais: o falhanço do grande esforço feito na sua recuperação e o mais que provável abandono que se segue não poderia deixar de sublinhar a precariedade de todo o controle sobre o espaço tendo em conta as oscilações da guerra na fronteira e a deslocação desta para os territórios a sul do Tejo que as conquistas de Lisboa e Santarém vêm viabilizar. Num quadro destes, em que a inoperância dos próprios andaluzes é manifesta - já o havia sido durante o final do século anterior, justificando a ocupação almorávida de que havia ainda memória fresca - a adesão à solução política almôada impõe-se como um dado incontornável, ainda quando signifique um considerável reajustamento ideológico. A consciência dessa inevitabilidade só poderá ter crescido com a reflexão feita pelo próprio Ibn Șāhị sobre o destino político dos principados taifa que floresceram durante os anos 40 e inícios dos 50 por todo o alAndalus e, com particular incidência no seu Gharb nativo. Deles o Autor escreveu a história, num livro sobre a revolta dos Muridines cujo texto se perdeu mas que sabemos já concluso em 1162 ( 557 H.), num momento, pois, em que se encontrava ao serviço dos almôadas como secretário da administração regional andaluza. A reflexão histórica encontra-se, aqui, duplamente determinada: pelas contradições próprias da sociedade andaluza, entre as oligarquias dominantes nas cidades e a plebe urbana, num momento em que despontam também indícios claros de uma agitação rural que a revolta de Ibn Qasī parece corporizar, entre a ortodoxia dos ulemas e dos fuqahă' e a dissidência de uma nova religiosidade popular, entre a resistência às cargas fiscais que a guerra impõe e a noção da ameaça cristã; determinada, por outro lado, pelo sucesso daquilo que no começo dos anos 60, que assistem à submissão de quase todo o al-Andalus aos almôadas - com a excepção do reino do irredutível Ibn Mardaniš, que se aguentará ainda mais alguns anos no Šarq se apresenta como o sucesso de governação de um poder estranho mas eficaz. E sobretudo incontornável. Tudo isto explicaria a fidelidade que demonstra no Al-Mann à dinastia almôada e que faz do seu texto um testemunho manifestamente comprometido com a fixação de uma memória ideológicamente conotada, em contraste, como já foi notado, com outras narrativas quase contemporâneas, tal a de 'Abd al-Wāḥid al-Marrākuši, que, escrevendo já do distante Egipto, se mostra mais lesto no exame crítico dos seus antigos senhores.

6 O tempo da sua circunstância adquire assim uma densidade especial no caso de Ibn Șāhịib, em parte porque vive numa época de mudanças sociais profundas, em parte porque a própria extensão e centralidade da sua carreira lhe permite tornar-se um observador privilegiado do seu tempo. De facto a sua vida biológica parece invulgarmente longa e há razões para crer que também o tenha sido o seu cursus honorum. Em 1198 (594H.), no final 
do reinado do terceiro califa almôada, Al-Manșūr, ainda vivia e continuava a trabalhar na sua história dos almôadas, uma vez que na parte sobrevivente do Al-Mann se refere a obras feitas nesse ano na mesquita de Sevilha, ${ }^{6}$ o que implica que pelo menos tenha retocado o texto - ou o tenha escrito na totalidade? - numa fase muito tardia. Não resta qualquer dúvida, pois, que mantém uma intervenção directa ou indirecta nos círculos ligados à dinastia reinante durante o governo dos três mais importantes califas, embora o grosso da sua actividade se concentre no reinado de Yūsuf. Quanto aos seus começos, os dados revelam-se mais confusos. Ibn Șāhị nada diz de directo sobre eles apesar da sua vocação para o testemunho presencial e para a história contemporânea fazer pensar que poderia ter acompanhado os sucessos que narrava na história perdida dos muridines. Tal presunção torna-se mais plausível se o identificarmos com o ulema biografado por Ibn alZubayr sob o nome de 'Abd al-Malik b. Muḥammad b. 'Ahmad b. Muḥammad b. 'Ibrāhīm, as kunyas de 'Abū Marwān e 'Abū Muḥammad, a nisba de al-Bājī e a šuhra de Ibn Șāhịib alȘalāt.7 Nome perfeitamente coincidente com aquele que figura no colophon do ms. da Bodleyan Library de Oxford - única tradição manuscrita conhecida do al-Mann - e que é o de 'Abd al-Malik b. Muhammad b. Șạhib al-Ṣalāt al-Bājī. É certo que mais 12 ulemas ostentam a mesma šuhra de Ibn Șāḥib al-Ṣalāt durante o período almôada, não sendo seguro que todos pertençam à mesma família. ${ }^{8} \mathrm{Em}$ nenhum dos outros casos, porém, se verifica tal coincidência dos elementos que compõem o nome, o nasab, ou patronímico, e a nisba pacense, pelo que a identificação me parece mais do que provável. Apenas uma incongruência cronológica é passível de suscitar dúvidas: este ulema teria morrido depois de 1145/6 (540 H.), o que significa que o autor do Dicionário lhe teria perdido o rasto depois desta data, talvez por não ter produzido mais nenhuma obra nas áreas das ciências religiosas ou do direito. A confirmar-se esta identificação isso significaria que Ibn Șāhib al-Ṣalāt teria tido uma carreira anterior ao seu percurso almôada, ocupando o lugar proeminente entre os letrados com expressão regional que o seu nascimento lhe proporcionava e que a adesão ao novo regime lhe teria facultado uma nova carreira agora ao serviço da administração andaluza e depois da central. o que melhor explicaria a profundidade da sua visão crónica.

7 Contudo, os dados verdadeiramente seguros sobre Ibn Șāhib só começam em 1162 (557 H.), no final do califado de 'Abd al-Mu'min, quando assiste aos preparativos para a sua derradeira campanha contra os reinos cristãos. Nesse ano já está ligado à administração almôada e numa função importante, visto ser um dos secretários, Kātib , que está com Barrāz b. Muhammad al-Masūfī, um xeque almorávida que se ligara precocemente aos destinos da dinastia almôada e que ocupara governos militares bem como a superintendência das finanças no al-Andalus durante os anos da sua lenta entrada na esfera de influência dos "unitários". ${ }^{9}$ Neste contexto, Ibn Șāhịib encontra-se envolvido no éfemero processo de transferência da capitalidade da administração andaluza, que se mantém autónoma no interior do Império, de Sevilha para Córdova, ${ }^{10}$ aparecendo ligado a funções na área fiscal e das finanças, domínio tanto mais nuclear quanto residia aí uma significativa parte do descontentamento crónico das populações andaluzas contra os seus governantes, assim como um dos núcleos centrais do programa de reformas empreendido pelos almôadas. ${ }^{11} \mathrm{Em}$ breve, contudo, a sucessão de um novo califa, viria repôr a capitalidade em Sevilha. O sucesso que Ibn Șāhib tem nos anos seguintes encontra-se directamente a ela ligado: Yūsuf I é o seu califa e os anos 60 parecem corresponder ao auge da sua carreira documentada. 
O centro dessa carreira talvez seja a provável conversão ao Tawhịd , o dogma definido pela pregação de Ibn Tūmart e que é o centro do credo almôada. Huici dá-a por certa, baseando-se numa passagem do Al-Mann em que Ibn șāhịib conta ter assistido pessoalmente às lições do alfaqueque Abū-l-ḥasan al-Išbīlī, xeque dos țālibes da corte, sobre a obra do mahdī ibn Tūmart. ${ }^{12} \mathrm{O}$ local e a data de tal evento são esclarecedores: Ibn Șāhiib encontrava-se na capital, Marrākuš, em 560 H. (1164-1165), menos de dois anos depois da morte de 'Abd al-Mu'min, e embora no texto não afirme de forma inequívoca a sua conversão ao Tawhìd, deixa pelo menos a certeza de um convívio intelectual e espiritual que se poderá associar a uma aproximação aos meios áulicos e à própria pessoa do novo califa. Com efeito, se pouco antes se encontrava em Sevilha, na esfera de um alto magistrado provincial, mesmo tão importante como Barrāz, agora reside em Marrākuš, a capital do Império, onde frequenta o palácio. Aí, precisamente, se encontra quando chega a notícia da vitória do sayyid Abū Ḥafș sobre Ibn Mardanīš, em Outubro desse mesmo ano de 1165 (560 H.), a qual, segundo ele, sentado no palácio entre os țālibes da corte e os xeques andaluzes, prediz, momentos antes da chegada das notícias do outro lado do Estreito. $O$ episódio é revelador da permanência do valor dos presságios enquanto processo de decifração do real futuro que havia sido próprio das sociedades antigas: enquanto Ibn Șāhị e os outros dignitários aguardam por novas da guerra de além Estreito, um jovem entra no palácio comendo um borracho, sinal inequívoco, diz logo o Autor, da vitória sobre Ibn Mardanī̌s. E explica-se, interpretando alegoricamente o quadro: o jovem, que parece um leão, são os almôadas; o borracho, os estrangeiros, leiase, o rei de Múrcia, o andaluz que ainda resistia à conquista almôada, mais os seus aliados castelhanos vindos de Toledo. A chegada imediata da notícia da vitória limita-se a confirmar o esperado. Está aberta a estrada para um controlo total do al-Andalus pelos seus novos senhores e, benignamente sentadas no palácio califal em Marrākuš, as elites andaluzas, colaborantes, celebram. "Estrangeiros", não apenas os cristãos mas os andaluzes não cooperantes: a adesão ao projecto político almôada não podia ser mais cabal, na medida em que se tornava, mais do que circunstância política, ideologia. 0 leão comia o seu borracho.

9 Além do orgulho jactante de um patrício de uma família regional projectado para os meios cortesãos, o episódio revela até que ponto Ibn Șāhị está no próprio centro do processo histórico do seu tempo. Não propriamente onde a acção se passa - a guerra de fronteira, evidencia-se, não é o seu habitat natural - mas no local para onde a informação e os acontecimentos confluem. Facto que ele próprio sublinha ao apontar como "uma das maravilhas do augúrio" o curto intervalo de tempo, apenas 16 dias, que a notícia da vitória demorou a chegar de Múrcia a Marrākuš. ${ }^{13} \mathrm{O}$ império é, deste modo, percepcionado como uma vasta rede de informação circulante que une espaços díspares e distantes tornados coesos pela partilha de uma obediência que é indestrinçavelmente religiosa e política e que se concentra e simboliza na pessoa do califa: a apropriação pelos almôadas da velha função califal, orgânica no mundo islâmico, mas no al-Andalus em eclipse desde a deposição do último omíada em 1031, ganha aqui todos os seus sentidos. Neste contexto, a leitura pública de cartas oficiais, como aquela que, redigida pelo secretário Ibn 'Ayyāš, dá detalhada conta aos sevilhanos da vitória sobre Ibn Mardanīš, ${ }^{14}$ assim como a recitação de poesias que neste e noutros casos as acompanham, são os veículos ritualizados da circulação de informação numa sociedade que é fundamentalmente escrituralística. A dimensão pública é pois garantida através da palavra, escrita e recitada publicamente, que de algum modo se constitui como o sangue 
que flui nas veias do império, garantindo a consequência dos necessários processos de identificação e integração. Por isso Ibn Șāhib, e muitos outros cronistas antes e depois dele, se dão ao trabalho de anotar pacientemente esses textos, que, amiúde, os tradutores modernos julgam inúteis. O que significa não só, obviamente, que eles eram guardados e registados - no caso das cartas oficiais a posição do Autor junto dos secretários da corte ter-lhe-ia possibilitado a consulta dos arquivos califais - mas também que os narradores da História os julgavam peças essenciais no desenrolar da acção. Pontos quentes onde a memória se cristalizava. Suspensões artificiosas no tempo em que a História, como numa solução química, se precipitava. A memória é por isso duplamente um assunto do grupo dos letrados de que Ibn Șāhib faz parte: porque são eles que finalmente a transformam em narrativa histórica, em ta'rīH , mas também porque a eles cabe pontuá-la através dos géneros poético e documental/administrativo, veiculando-a socialmente e constituindose eles próprios, por essa via, em agentes históricos.

10 A identificação do letrado cortesão com os seus senhores não poderia, pois, ser mais cabal. Filho de berberes do Atlas, na sua raiz iletrados, mas vertido na dupla matriz escrituralística alcorânica e mahdita, o império constrói-se sobre os letrados, antes de mais os andaluzes, tanto como sobre a organização militar das cábilas. O que justifica a presença constante de um grupo de alfaqueques e ulemas junto da corte, mesmo quando o califa viaja ou se encontra em expedição militar. Nesses anos seguintes Ibn Șāhị está entre eles, embora não pertencendo à primeira linha. A sua presença intui-se, umas vezes, pelo rigor do detalhe na narrativa e por um certo olhar que resulta da exposição directa aos eventos; comprova-se, outras, pela passagem do Autor a um discurso na primeira pessoa, que testemunha a sua participação nos acontecimentos e, sobretudo a condição de espectador deles. Um momento particularmente revelador desse modo discursivo corresponde à campanha de Huete, que o califa empreendeu no Verão/Outono de 1172 (567/568 H.), com a cópia de meios, a espectacularidade ritual e os resultados indecisos que muitas vezes caracterizaram as ofensivas almôadas contra o al-Andalus, em que a dimensão militar parece inseparável da função integradora do império que cumpriam, reunidas as cábilas berberes e os contingentes árabes e andaluzes em torno do califa, dos sayyides, dos letrados e, sobretudo, do Tawhìd que aquele corporizava, concentrados todos no objectivo que era, em simultâneo, a manifestação máxima do poder califal e a sua mesma razão de ser, a jihād. Justamente porque nela participou, e porque foi a primeira campanha de Yūsuf no al-Andalus, mais do que pela sua importância militar efectiva, Ibn Șāhib concede-lhe um largo espaço na narrativa, relatando-a quase dia a dia. Não nos interessam aqui os seus sucessos - uma longa expedição de 5 meses, entre inícios de Junho e os começos de Novembro, decorridos entre a partida de e o regresso a Sevilha, durante a qual se saquearam e destruiram várias terras e castelos mas se falhou o objectivo inicial da conquista de Huete - mas o que revelam, por um lado sobre as formas de fixação da memória e da construção da narrativa pelo Autor, por outro, sobre a evolução da sua perspectiva face ao regime que serve.

11 Assinale-se, para começar, que embora o uso da terceira pessoa seja dominante em toda a narrativa, o Autor resvala aqui mais vezes do que é habitual para a primeira. Tal acontece sobretudo quando sai da escala das grandes personagens e eventos maiores, para a da pequena história do quotidiano da expedição, e relata a dificuldade que sente em encontrar alimentos, chegando a comprar um punhado de figos pela exorbitante quantia de um dirham, o que o levará à cidade de Valência, onde acaba por se abastecer. Aqui a curiosidade de viajante fá-lo-à deter-se nas belezas locais ao mesmo tempo que vai 
anotando, de passagem, serem já visíveis "a sua debilidade", estendendo-se o medo das revoltas: o historiador, atento, cruza os tempos, o da observação e aquele em que escreve, com toda a probabilidade muitos anos depois. $\mathrm{E}$ faz da sua própria memória fonte, contornando o taqlī , a transmissão acrítica da autoridade recebida, que serve de base a uma substantiva parte da História que então se fazia em árabe, uma reiterada transmissão das fontes dadas como boas, aglutinadas em novo formato. 0 próprio Ibn Șāhị viria, no século seguinte, a ser incorporado nessa cadeia de transmissão, quando o polígrafo Ibn 'I suficientemente próxima para se poderem identificar presumíveis passagens inteiras da parte perdida do Al-Mann. Enquanto narrador de uma história contemporânea abre-se porém ao Autor todo um outro conjunto de possibilidades: a preeminência do taqlīd enquanto forma de pensar a relação com um passado através de uma autoridade que é em simultâneo mediadora e avalizadora, dá lugar a uma relação pessoal, feita de memórias próprias e alheias, mas todas resultantes de um processo de elaboração interno ao sujeito observador/historiador. Como alguns séculos mais tarde haveria de propôr como modelo Ibn Khaldun, a História como disciplina terá de superar o bloqueamento que vem da reprodução acrítica através do ijtihād, o esforço de reflexão racional sobre os fenómenos. ${ }^{15}$ Sem disso ter seguramente clara consciência, Ibn Șāhị trilhava no Al-Mann esse mesmo percurso, ao libertar-se, pela própria contemporaneidade dos eventos narrados, dos bloqueamentos colocados pelas cadeias historiográficas de transmissão. E é neste contexto que o discurso directo assume o seu pleno significado enquanto ponto de partida de um ijtihād prático. Na narração, muito carnal, daquele episódio por ele vivido na campanha, em fórmulas como "eu o vi quando chegou", na referência ao testemunho de fontes dele próximas - "Contou-me Abū-1-'Ala b. 'Azzūn e disse-me [...]" - o Autor passa o limiar da História tradicional para entrar num registo memorialístico. ${ }^{16}$

É aqui também, na primeira pessoa, que ele se afasta mais do peso que as convenções impostas pelo seu grupo e pelo próprio género literário cultivado e ainda pela necessária fidelidade aos seus senhores almôadas, lhe impõem na maior parte da narrativa. A retórica panegírica pode assim dar lugar a um exame crítico que mina os próprios fundamentos da aceitação do programa ideológico almôada. Em todo o relato da campanha de Huete perpassa um distanciamento do modelo de acção que dele decorre e uma crítica velada à inutilidade do esforço dispendido, resultado de um desinteresse em levar até ao fim o objectivo estratégico que teria sido a conquista da praça. Ou, mais precisamente, a consciência do desfasamento entre a forma mental dos andaluzes e a das chefias almôadas, a começar pela do próprio califa Yūsuf, que Ibn Șāhị normalmente tanto incensa, e do influentíssimo sayyid Abū Ḥafș, mais dispostos a discutir pontos de doutrina e dogma do que uma efectiva acção militar. As amargas queixas que o Autor põe, em discurso directo, na boca do xeque Abū-1-'Ala b. 'Azzūn, reflectem isso mesmo: estando prestes a obter a vitória no combate perante a torre de Huete, este solicita a intervenção do califa e do sayyid que, ignorando-o, persistem na discussão teológica em que estavam embrenhados, o que acabará por ditar o abandono do assédio à praça. $\mathrm{A}$ logística da expedição não escapa também às observações do Autor. E a exclusão das distribuições de mantimentos dos que não estavam inscritos nos registos nem tinham qualquer cargo, que a carestia que a guerra sempre endémicamente provocava vinha tornar particularmente gravosa, porque o abrange,$^{17}$ não passa despercebida. $O$ tom de distanciamento é, aqui, evidente. Traduz, afinal, uma perspectiva muito diferente não apenas sobre a guerra mas sobre o mesmo processo histórico, entre andaluzes e almôadas. Para os primeiros a jihād é guerra santa mas antes de mais uma questão de sobrevivência 
de um modo de vida num território ancestral. Para os segundos, de certa forma esgota-se em si mesma, enquanto eixo vertebrador do império e da função califal. E o seu resultado, sem dúvida significativo e prestigioso, menos relevante que o acto em si. Neste quadro nenhuma razão para estranhar, como o faz Ibn Șāhib, que as questões doutrinárias se apresentem tão importantes quanto a aç̧ão militar propriamente dita. Criado nas difíceis realidades da fronteira andaluza, numa sociedade em que a defesa do espaço se apresenta como o problema mais premente e que por isso tolerava o domínio de poderes estranhos vindos de além Estreito, a dimensão ritual da guerra parece em parte escapar-lhe.

13 E apesar da explícita tentativa, que é o Al-Mann, para promover a colagem das elites andaluzas ao programa almôada, colocando a pregação de Ibn Tūmart no centro da história contemporânea, as sementes da dúvida e da descrença que espreitam por entre o panegirismo dominante são, em extremo, reveladoras do artificialismo que ela encerra - e que a rapidez com que se desmorona o mundo almôada no Al-Andalus dos finais da década de 20 de Duzentos mais confirma - assim como da complexidade do dilema que essas elites por então enfrentam: ceder ao Tawhịd ou colapsar perante as cada vez mais ameaçadoras forças cristãs. E se a escolha pela primeira opção é inequívoca, mais cedo, é certo, no Gharb de onde o Autor era originário, do que no Šarq, onde a resiliência das soluções urbano-regionais andaluzas se prolonga ainda algumas décadas, ela não se faz sem os custos inerentes à co-habitação com um programa ideológico tão diferente do seu próprio. A nuclearidade do mahdismo enquanto propulsor do processo histórico, em particular, - e pesem embora as tentações messiânicas por que tinham enveredado alguns dos movimentos de coloração șūfi que se difundem no al-Andalus nos anos 40 do século XII, sobretudo no caso do movimento liderado por Ibn Qāsi de que Ibn Șāhib haveria de narrar as vicissitudes - é de molde a encontrar um sério obstáculo no conservadorismo letrado maliquita das elites andaluzas a que o Autor pertence pela genealogia do sangue como pela do pensamento. Problema tanto maior quanto, como alguns fragmentos do AlMann, sobreviventes no Bayān, bem documentam, ${ }^{18}$ os afloramentos mahditas dos anos 40 , no próprio território andaluz, parecem ter como pano de fundo uma conflitualidade social que levanta os campos e mantém nas cidades uma luta aberta pelo poder entre os grupos tradicionais, a plebe urbana e uma população indiferenciada.

14 A narrativa de Ibn Șāhị constitui-se, assim, como a de uma dupla redução a que a sociedade andaluza é sujeita: ao inevitável domínio político e militar dos almôadas, por um lado, ao controle ideológico do Tawhìd, pelo outro. E a retórica panegirista de servidor da nova dinastia africana que faz parte das regras do jogo do relacionamento entre os letrados e os poderes instituídos numa sociedade islâmica, não é suficiente para escamotear completamente a consciência desse facto. Sobretudo e desde logo porque nunca Ibn Șāhib perde a noção da alteridade dos almôadas face aos andaluzes - e mesmo das tribos árabes, que fazem parte dos contingentes militares recém-chegados, face a ambos - ainda que a capacidade de integração revelada pelos novos senhores, bem como a sua penetração na sociedade andaluza, se mostre mais eficaz que a dos seus predecessores almorávidas. Contudo, e apesar da conversão, ao menos formal, ao Tawhịd, de representativos sectores da sociedade regional, a consciência identitária andaluza no interior do império não parece nunca afectada, manifestando-se numa resistência que, como mostrou Maria Jesús Viguera, ${ }^{19}$ não desaparece com o fim dos últimos reinos taifa levantinos, e se mantém suficientemente viva para ressurgir com Ibn Hūd aproveitando a agonia do regime almôada. É precisamente essa consciência que explica o disfarçado azedume que caracteriza o relato já citado da campanha de Huete, num modo menor e, 
num maior, a ambiguidade que me parece percorrer uma visão da história implícita no AlMann.

15 Com efeito, o dilema da aceitação dos novos senhores não é puramente da ordem do poder ou da política mas ideológico e prende-se, na caso das elites andaluzas também, como salientou Maribel Fierro, ${ }^{20}$ com a sobrevivência de um maliquismo que lhes era endógeno. Sendo o Autor um ulema, a sua conivência com as novas e revolucionárias propostas doutrinárias almôadas, não se pode fazer sem contradição: entre as fidelidades ancestrais, ao maliquismo, ao estatuto privilegiado do grupo de oligarcas letrados a que pertence, a uma identidade andaluza em que a memória já longínqua do califado omíada desempenhava função unificadora, e as novas fidelidades, ao Tawhịd, ao protagonismo de novos senhores e de uma nova aristocracia imperial, cuja preeminência resulta da sua proximidade genealógica ao grupo de companheiros de Ibn Tūmart, a uma nova família real, por fim, já não árabe andaluza, como os omíadas, mas berbere. Na raiz, ilegítima, portanto. Porque não andaluza, porque não árabe - nem sequer arabófona, no início porque desligada de qualquer relação genealógica com a família do Profeta capaz de garantir a sua legitimidade. Fora, pois, do Islão enquanto processo histórico e memória. Mesmo, pela heterodoxia da sua proposta religiosa, em ruptura com ele. E ainda mais quando os líderes do movimento assumem os títulos reservados aos sucessores do Profeta enquanto chefes da comunidade dos crentes, Imām , Califa, Amir al-Mu'minin, na proclamação aberta e belicosa de uma nova legitimidade que ninguém no Islão Ocidental, nem os emires almorávidas, nem os príncipes taifa do século anterior, ousara desde o fim do califado omíada. De certa forma trata-se de uma translatio, como aquela que os teóricos de outro poder imperial, o romano-germânico, vinham propondo nas últimas duas centúrias.

16 Dela, assumidamente, o Al-Mann pretende ser peça relevante. Uma proposta explicitada logo no título da obra: "O dom do imamato para os que não mereceram que os colocasse Deus como imans e os pôs como seus herdeiros e a aparição de al-Mahdi dos almôadas contra os velados e o que se seguiu a isto com o califado do califa e príncipe dos crentes "Abd Al-Mu'min, um dos califas ortodoxos". ${ }^{21} \mathrm{~A}$ obra é assim, voluntariamente, não apenas História Dinástica, ${ }^{22}$ narrativa da ascensão ao poder de uma nova dinastia em substituição dos "velados" almorávidas, mas o testemunho de uma nova era e de uma nova legitimidade na liderança da Umma, marcada, enquanto momento de ruptura, pela pregação do mahdī Ibn Tūmart. Por esta via assume, logo desde o colophon, uma colagem ao núcleo do programa ideológico almôada, que vai sendo glosada ao longo da obra, nos panegíricos oficiais aos califas, na centralidade da sociedade de corte que os rodeia, na selecção heurística que, dispensada pela contemporaneidade dos temas e da cronologia do apelo constante ao taqlid, pode beber directamente nas cartas oficiais a que o Autor tem acesso, como no acervo das memórias individuais, dele e dos seus próximos, amigos e familiares. Colagem, finalmente e sobretudo, na própria estrutura narrativa, cronológica, as mais das vezes, sem ser nunca analística - e as analepses, não infrequentes, estão aí para o provar - obedecendo a um fio condutor que é sempre o do destino do novo império. Essa identificação com um programa político está longe, porém, de ser linear.

Nesse sentido, a cooperação com o projecto ideológico/visão da história almôada há-de estar marcada por uma ambiguidade entre a exaltação da memória dinástica imperial que percorre toda a obra e a presença subtil de uma memória à escala regional. Andaluza, pois, e não magrebina. Nela se constela uma consciência identitária que a inquestionável mas não acrítica fidelidade aos califas almôadas não belisca. 

parte sobrevivente da obra, surgem como personagens centrais da narrativa - o que é de resto consentâneo com uma concepção do califado que, como notou Manuela Marin, ${ }^{23}$ diverge da antiga tradição omíada e abássida, essencialmente cerimonial e palaciana, bem assim da fatímida, essencialmente processional, preferindo colocar o califa no centro de eventos públicos de grande escala, em que as campanhas militares ocupam relevante papel e que é mesmo dentro desta concepção do califado que a narrativa encontra a sua função ideológica primeira - também é verdade que, num plano secundário mas decisivo, vai assomando toda uma galeria de personagens quase invisíveis que assistem aos acontecimentos neles participando como actores secundários. Neles está o grupo dos andaluzes a que o Autor pertence e sobretudo ele próprio enquanto testemunha presencial, presumida, quase sempre, declarada, outras vezes. E é precisamente por aí, através dessa dimensão memorialística que a história se faz regional sem deixar por isso de ser dinástica. Mantendo, muito embora, o norte no processo político almôada, percorrendo as regiões do império, Ibn Șāhib nunca perde completamente a perspectiva andaluza e mesmo um olhar que vem do Gharb, pelo protagonismo que este detém na narrativa e que passará ao texto do Bayān que o cita. infiltra-se assim uma memória regional, sociologicamente conotada, a de um grupo de oligarcas letrados provenientes das velhas cidades andaluzas que, zeloso do seu passado mas consciente do desafio contemporâneo, um desafio de sobrevivência, soube colaborar com os novos senhores magrebinos e adaptar-se às transformações ideológicas e factuais - na omnipresença do Tawhìd, no re-centramento dos poderes locais e regionais - que o seu domínio impunha. Que soube escapar a ser do leão almôada o borracho.

\section{NOTAS}

1. Trad. castelhana por E. Garcia Gómez, É. Lévi Provençal, El Siglo XI en primera persona. Las "Memorias" de 'Abd Allāh , último Rey zīrí de Granada destronado por los almohades (1090), Madrid, 1980 e inglesa por Amin T. Tibi, The Tibyān. Memoirs of 'Abd Allāh b. Bulluggīn, last Zīrid Amīr of Granada, Leyde, E. J. Brill, 1986. Uma breve descrição do ms. por Pascual de Gayangos em Al-Makkarí, The History of the Mohammedan Dynasties in Spain [...] Nafhu-T-Tíb [...]. London, Oriental Translation Fund, 1843, II, pp. 518-519.

2. Ibn Șāḥib al-Salāt, Al-Mann bi-l-imāma, ed. 'Abd al-Hādī al-Tāzi, Beyrouth, 1964 e trad. por A. Huici de Miranda, Valencia, Anubar Ediciones, 1969, a que se referem as citações feitas aqui.

3. Idem, pp. 6-7, embora nem todas as ilações sobre a vida do Autor que retira do texto e elenca neste prefácio resistam a um confronto com as afirmações do próprio Ibn Șāhiib. Sobre o Autor cf. Francisco Pons Boigues, Los Historiadores y geógrafos arábigo-españoles, 800-1450 A.D.. Amsterdam, Philo Press, 1972 [aliás, Madrid, 1898], pp. 245-246 e Pascual de Gayangos, op. cit., pp. 518-519. e, sobretudo, Maria Jesús Viguera Molíns, "Historíografia" in Maria Jesús Viguera Molíns, El Retroceso territorial de Al-Andalus. Almorávides y almohades. Siglos XI al XIII. Madrid, Espasa Calpe, 1997, pp. 10 e 28 J. F. P. Hopkins, s.v. "Ibn

Șāhịib al-Salā", E.I., 2ªed., III.

Cultura, Vol. 23 | 2006 
4. O próprio Autor cita dois irmãos no texto. E as nomina de sábios que têm sido publicadas nos E.O.B.A., referem vários indivíduos com esta šuhra, sobretudo nos períodos mais tardios. Voltarei a este assunto em artigo que preparo sobre os Banū Șahib al-Salāt.

5. O relato deste processo, pontuado por uma tentativa de reocupação almôada temporariamente bem sucedida está em Ibn Idari, Al-Bayān al-Mugrib, trad. A. Huici de Miranda, Tetuán, Editora Marroquí, 1953, I, pp. 8 e ss., numa passagem onde este compilador mais tardio retoma de resto o texto original da parte perdida do Al-Mann.

6. Al-Mann, p. 6 do "Prologo". Hopkins, ibidem, diz que ainda vive em 1203 (600 H.).

7. Mayte Penelas, Jesús Zanón, "Nómina de ulemas andalusíes de época almohade", E.O.B.A., IX, p. 91, nº 1057.

8. Idem, no․ 47, 159, 434, 1021, 1192, 1440, 1635, 1638, 1752, 1770, 1811, 2393.

9. A. Huici, Historia Politica del Imperio Almohada, I, pp. 146, 190 e especialmente 204, 205, 216.

10. Al-Mann, pp. 48-49; Huici, op. cit., pp. 204-205.

11. A relação de Ibn Șāhịb com este projecto de 'Abd al-Mu'min não surge inteiramente clara no texto: parece primeiro ter-se escusado a colaborar nele, mas depois está em Córdova, com os restantes dignitários e com os 82 homens que aí haviam permanecido durante a fitna de Ibn Hamušk, a receber os princípes almôadas que vão tomar conta da cidade. Provavelmente opunhase à transferência da sede califal na Península, muito mais o produto de uma tentativa de capitalização do prestígio da memória omíada pela dinastia norte africana, do que o resultado de uma atenta observação das circunstâncias locais. Essa provável relutância de funcionário andaluz devia pois ser feita tanto de interesse pessoal - Sevilha era o centro natural de atracção de todo o Gharb, de onde a sua família era originária - como de realismo político: se Córdova representava o passado califal legitimista, Sevilha era agora, inequivocamente, o grande centro urbano do alAndalus e a sua chave. No programa de 'Abd al-Mu'min, o primeiro califa almôada, isso parecia contar menos, porém, que a colagem ao passado omíada ou a importância dada ao repovoamento da cidade: "Chegou-lhes a excelsa ordem para se estabelecerem em Córdova [...] para que fosse a sede do governo no al-Andalus, como a tiveram os Banu Ummaya por seu antigo direito, já que ocupava o centro do al-Andalus [...]". Ao argumento da legitimidade vem assim, ainda sobrepôrse um outro de centralidade territorial que tem por detrás de si uma manobra táctica. Deslocar a sede para Córdova significava uma aproximação à fronteira, uma vez que o Levante estava, por então, ainda nas mãos das segundas taifas. Huici, ibidem.

12. Al-Mann, pp. 60-61.

13. Idem, p. 79.

14. Idem, pp. 79-85.

15. Ali Oumlil, L'Histoire et son discours. Essai sur la methodologie d'Ibn Khaldoun, $2^{\mathrm{a}}$ ed.. Rabat, Publications de la Faculté des Lettres et des Sciences Humaines à Rabat/SMER, 1982, pp. 68 e ss.; Ibn Khaldûn, The Muqaddimah. An lntroduction to History, trad. F. Rosenthal, $2^{\mathrm{a}}$ ed.. London, Routledge \& Kegan Paul, 1967, vol. I, pp. 15,16 e ss.

16. Al-Mann, respectivamente, pp. 223, 231, 211.

17. Já não estava, nesse momento, Ibn Șāhib ligado à administração almôada? Resultará daí a mudança de tom?

18. Esses conflitos estão documentados pelo menos no caso de Beja, a cidade-de origem de Ibn Șāhiib. Cf. Ibn Id dari, Al-Bayān , I, 11-13.

19. Maria Jesús Viguera Molins, "Las reacciones de los Andalusíes ante los almohades" in Patrice Cressier, Maribel Fierro, Luis Molina (eds.), Los Almohades: problemas y perspectivas. Madrid, C.S.I.C., 2005, II, pp. 705-735.

20. Maribel Fierro, "Doctrina y práctica jurídicas bajo los almohades" in Patrice Cressier, Maribel Fierro, Luis Molina (eds.), Los Almohades: problemas y perspectivas. Madrid, C.S.I.C., 2005, II, pp. 895-935. 
21. Al-Mann, p. 11. A tradução que Pons Boigues dá, citando M. Amari, é menos literal mas também menos confusa: "Crónica da concessão do pontificado àqueles que não eram considerados dignos que os elevasse Deus a esta dignidade, e foi aqui que Deus lhes concedeu a soberania fazendo-os herdeiros [do Império]. E aparição do Imam o Mahdi dos almôadas [...]". Francisco Pons Boigues, op. cit., p. 246. E ainda outra variante por P. De Gayangos, op. cit., p. 519: "O dom do imamato concedido àqueles que se consideravam os menos dignos dele; e a sua nomeação por Deus para serem Imans e chefes [do povo] e os herdeiros [do império]. Ou a aparição do Imam e Mahdi dos almôadas". Considere-se ainda a de M. J. Viguera, "Historiografía", p. 10.

22. Cf. Franz Rosenthal, A History of Muslim Historiography. Leiden, E. J. Brill, 1952, pp. 77 e ss.; C. Brockelmann, Geschichte der Arabischen Litteratur. Leiden, E. J. Brill, 1937, I (Suplemento), p. 554, que inscreve o Al-Mann na secção "História Dinástica".

23. Manuela Marín, "El califa almohade: una presencia activa y benéfica" in Patrice Cressier, Maribel Fierro, Luis Molina (eds.), Los Almohades: problemas y perspectivas. Madrid, C.S.I.C., 2005, II, pp. 451-476.

\section{RESUMOS}

No quadro genérico da proposta "Tempo e Temporalidades", aqui num horizonte islâmico, partese de um ponto de vista assumidamente fragmentário e regional, intentando alcançar uma posição de observação no interior da concepção do tempo histórico e da memória. Observa-se, assim, a obra e a vida de Ibn Șāhib al-Salāt, proveniente de uma família de notáveis de Beja, procurando seguir os acidentes na formulação de uma memória regional no contexto de uma construção política de modelo imperial como a almôada. No limiar entre as práticas heurísticas e hermenêuticas, regista-se uma rejeição de facto do taqlīd e uma opção pelas memórias pessoais e pelas fontes primárias, consentâneas com o registo de uma história contemporânea que passa ao lado de uma concepção universal islâmica da história.

Disregarding the broader view of a particular islamic conception of time, I try here to take an explicitly fragmentary and regional standing point. Observing the work and life of a late twelfth century chronicler from the western part of al-Andalus, Ibn Șāhịib al-Salāt, and bearing in mind both his affiliation to the andalusian aristocracy and his connection to the almohad administration, some questions are argued. Firstly I aim to establish the importance of a regional point of view within an Empire that was by that time as large and apparently as stable as the almohade. Also we have to take into consideration the role played by mahdisme around Ibn Tumart. Did it affect the notions on history among the non-almohade elites? Finally, I try to establish the terms of an historical practice, which clearly refuses taqlīd and favours oral testimony and primary sources aiming for a contemporary history.

\section{ÍNDICE}

Keywords: memory, andalusian arabic historiography, taqlīd/ijtihad, regional elites

Palavras-chave: memória, historiografia árabe andaluza, taqlīd/ijtihad, elites regionais 


\section{AUTOR}

\section{HERMENEGILDO FERNANDES}

Faculdade de Letras. Centro de História da Universidade de Lisboa

Licenciado pela FCSH da UNL. Professor Auxiliar no departamento de História da Faculdade de Letras da Universidade de Lisboa, onde exerce funções docentes desde 1987 e onde tem leccionado cadeiras no âmbito da História medieval e da História do al-Andalus. Doutorou-se em 2001 na Universidade de Lisboa, com uma tese intitulada "Entre Mouros e Cristãos. A sociedade de fronteira no sudoeste peninsular interior (séculos XII-XIII)" e desde então a sua actividade de investigação concentra-se nos problemas da transição entre a sociedade islâmica e os reinos cristãos e na formação das elites urbanas. Colaborou com textos na História de Portugal dirigida por João Medina, Ediclube, Amadora, 1992, vol. 3 e na Nova História de Portugal, dirigida por A.H de Oliveira Marques, vol. 3, Portugal em Definição de Fronteiras (1096-1325). Do Condado Portucalense à crise do Século XIV, coord. de Maria Helena da Cruz Coelho e Armando Luís de Carvalho Homem. Lisboa, Editorial Presença, 1996. É autor de D. Sancho II. Tragédia, Lisboa, Círculo de Leitores, 2006. 